\title{
Lifelong Learning Key Competence Levels of Graduate Students"
}

\author{
Abdurrahman Adabaş ${ }^{1, *}$, Hüseyin Kaygin ${ }^{2}$ \\ ${ }^{1}$ Ministry of National Education(MEB), Turkey \\ ${ }^{2}$ Faculty of Education, Bartın University, Turkey
}

Copyright $\mathrm{C} 2016$ by authors, all rights reserved. Authors agree that this article remains permanently open access under the terms of the Creative Commons Attribution License 4.0 International License

\begin{abstract}
The European Union defines lifelong learning as all activities aimed at improving an individual's knowledge, skills and competences individually, socially or vocationally throughout his/her life. In 2007, eight key competences necessary for lifelong learning were identified by the European Union Education and Culture Commission. These competences are communication in the mother tongue, communication in foreign languages, mathematical competence and basic competences in science and technology, digital competence, learning to learn, social and civic competences, sense of initiative and entrepreneurship and cultural awareness and expression. The main purpose of this research is to determine the key competence levels of postgraduate students in lifelong learning. It was concluded that lifelong learning competences of the graduate students participating in the study were high. Moreover, the graduate students considered themselves best at the native language communication competence, while the lifelong learning key competence at which they considered themselves worst was foreign language communication competence.
\end{abstract}

Keywords Lifelong Learning, Competence, Graduate Students

\section{Introduction}

In the 21st century, where we live the information age and the technology changes and develops every day; people need to keep up with this change and care about their personal developments. Countless technological devices such as intelligent ventilating systems, driverless cars, plant-house tracker systems, tablet computers and smart watches are introduced nearly every day and what people need in this regard is lifelong learning to be able to keep up with all those technological developments and catch the era. The place and the importance of education carried out in formal education institutions are undeniable for an individual's personal development. Moreover, today it can be clearly seen that life-long learning in terms of formal education, non-formal education and informal learning is needed by individuals of 21 st century to have the standards of this information age.

With the changes and developments taken place in time, lifelong learning played an important role in the people's and society's courses of life until the 21 st century. Today as a consequence of globalisation and developments in information technology, a new development model based on human is tried to be created. Raising a productive and flexible workforce is the critical basis of success for nations to be internationally competitive. In this regard, lifelong learning becomes vitally important to enhance human resource with the qualifications required [1]. On the other hand, children, old people, disabled people, immigrants in the country, unemployed people, people with low income, low skilled workers, low-income workers, persons living far away from learning centers and disadvantaged groups are the primary objectives of LLL. The events should be organized for these people to increase their training demands, life awareness and life quality and the organizers should be supported [13].

The term of lifelong learning which is seen as an important way of increasing the qualifications of individuals has been defined in different ways by researchers. The European Union defines the term lifelong learning as the all activities which aim developing individual's information, skills, competences by means of individually, socially or professionally [6]. The specialties of lifelong learner individuals have been described as being able to control his/her own learning process, having self-control, taking responsibility, being open to innovations and change, orientating, using high level thinking skills such as problem solving, being eager to communication, having competence of using information and communication technologies [5].

In 21 st century there have been changes in various fields such as in forms of living, learning and working. In such a process, it seems impossible that education systems can successfully manage in their service without any change [1]. And it seems impossible for individuals to compete in today's labor market, to respond the needs of society with 
what they have learnt in the education systems which have never changed. Because in today's world where we pass from agricultural society to industrial society and from industrial society to information society; in economy, military, society and in many other professions the expectations and standards have shifted. Many things that could have been done only with manpower in the past have become easier to do by using only a button in this information age where science and technology have unbelievably developed and as a result of all of these, the qualification and competence expectations from individuals have changed. So especially in European Union member countries there have been studies about competence.

According to Key Competences Workgroup, the term 'key competences' is referred to as all kinds of transferable, multifunctional information, skills and manners that are required for personal happiness and personal development, involvement and employability. This competences were clarified as having to be developed until the end of compulsory education or learning and being a base for the next learning step as a part of lifelong learning [7]. According to the definition of Workgroup, key competences are important for the individual in terms of having a job and for the educational life in the future.

There have been different key competences about lifelong learning suggested by variety of researchers. However, in 2007 under the name of 'The Eight Key Competencies for Lifelong Learning - European Framework' eight key competences needed for lifelong learning were determined by the European Union Education and Culture Commission. The competences determined by the commission were collected under eight titles. These are; communication in the mother tongue, communication in foreign languages, mathematical competence and basic competences in science and technology, digital competence, learning to learn, social and civic competences, sense of initiative and entrepreneurship and cultural awareness and expression [7].

The Commission defined communication in mother tongue as 'The ability to express and interpret concepts, thoughts, feelings, facts, and opinions in both oral and written form; listening, speaking, reading, writing and to interact linguistically in an appropriate and creative way in a full range of societal and cultural contexts; in education and training, work, home and leisure' [7]. An individual whose competence in communication in the mother tongue is in good level, has qualifications such as expressing his/her feelings and thoughts effectively and interpreting the ideas.

As indicated by European Commission competence of communication in foreign languages depends on the capacity to comprehend, express and interpret concepts, considerations, emotions, facts and opinions in both oral and written form (listening, speaking, reading and writing) in an appropriate range of societal and social settings (in education and training, work, home and leisure) according to one's wants or needs. Communication in foreign languages also calls for skills such as mediation and intercultural understanding [7].

Mathematical competence is the capacity to create and apply mathematical thinking in order to tackle a range of problems in ordinary circumstances. Competence in science refers to the capacity and readiness to utilize the body of knowledge and methodology employed to clarify the natural world, in order to identify questions and to draw evidence-based conclusions [7].

Digital competence requires a sound comprehension and knowledge of the fundamental PC applications such as word processing, spreadsheets, databases, information storage and management, and a comprehension of the opportunities of leisure, information sharing and collaborative networking, learning and research [16].

Learning to learn is the ability to pursue and persist in learning, to organise one's own learning, including through effective management of time and information. Developing the thinking skills provides using individual's intelligences [12]. This competence means gaining, processing and assimilating new knowledge and skills as well as seeking and making use of guidance [7].

Social and civic competences incorporate individual, interpersonal and intercultural competence and cover all types of conduct that prepare people to partake in a successful and productive path in social and working life, and particularly in increasingly diverse societies, and to resolve conflict where necessary [7].

Sense of initiative and entrepreneurship refers to an individual's ability to transform ideas into action. It contains creativity, innovation and risk-taking, as well as the ability to plan and manage projects in order to achieve objectives [7].

Cultural awareness and expression alludes to valuation for the significance of the imaginative articulation of thoughts, experiences and emotions feelings in a scope of media, including music, performing arts, literature, and the visual arts [7].

At this point in Turkish Education System, some qualifications and competences are required from individuals who continue their learning life starting from primary education to graduate education. Hence graduate education which is expected to solve the economic, social, technology, education and culture related problems holds also an important place in terms of its power to create the qualified human power, raising the academic members, researchers that the universities need. Graduate education is also an education process which contributes to the development and improvement of the society with its function to raise expert individuals who practice the technology, use its productions and perform the service of producing [3].

In this regard, it becomes significant to determine in which stage the individuals in Turkey who finished primary, secondary and higher education and now continue to graduate education are in terms of the eight key competences determined by European Commission.

This study aims to determine graduate students levels of lifelong learning key competences. Within this scope, the 
following sub-problems were sought:

1. What is the level of the graduate students' lifelong learning competences?

2. Do the lifelong learning competences of graduate students significantly change according to their genders?

3 . Is there any significant difference between the levels of graduate students lifelong learning competences and the stage they are in graduate education?

4. Do the levels of lifelong learning competences of graduate students change significantly according to their school types?

\section{Method}

In this research relational screening model which aims to determine the variance and variance degrees between two or more factors [9] was used. The population of this research is composed of 752 graduate students majoring at the Graduate School of Education Sciences, Graduate School of Applied and Natural Sciences and Graduate School of Social Sciences in Bartın University, in 2014-2015 academic year. And this research's sample is composed of 262 students who were chosen among these students with simple random ways. In the research Questionnaire of Personal Information was used to obtain personal information about graduate students and the Scale of Key Competence in Lifelong Learning which was developed by Şahin, Akbaşlı and Yanpar Yelken [14] was used to determine the levels of key lifelong learning competences of the students. The Scale of Key Competencies in Lifelong Learning developed by the researchers reviewing the related literature is a likert type of scale and composed of 8 sub-dimensions with 3 items. The sub-dimensions of the scale are competence in mother tongue, competence of communication in foreign languages, mathematical competence and basic competences in science and technology, digital competence, competence of learning to learn, social and civic competences sense of initiative and entrepreneurship and cultural awareness and expression. The scale was analysed in terms of reliability and validity. The Cronbach Alpha reliability coefficient was found 0,88 and the KMO test result was found 0,86 by the researchers. The Cronbach Alpha reliability coefficient of the results was found to be 0,88 in this study.

While determining if the data are distributed normally or not; if the group is more than 50 members; Kolmogorov-Smirnov test is carried out. When the p-value of the test result is more than 0.05 , it shows that significance level of scores is not distributed in significant deviation. When the distribution of the data show excessive deviation than normal, statistics that require 'normality' supposal should not be used. [2].

Because the size of the scale group is more than 50, Kolmogorov-Smirnov test was used and kurtosis index was surveyed. And consequently, it showed that both on the whole scale and in full size data are not normally distributed. $(p<0.05)$. So while analysing the data, tests that do not require normality were used. The Mann-Whitney U Test was used to find out whether there was a significant difference between the stage variations of two groups in terms of graduate students' genders and key lifelong learning competences. Kruskal Wallis H Tests were used to compare the levels of lifelong learning competences between groups of students with regard to the graduate schools they study.

\section{Findings}

In this section, firstly, the distribution of the participants in terms of graduate school types were presented. Then, the findings obtained as a result of statistical analysis of the data gathered and the comments about those findings were given in the order of sub-problems. The findings are shown as below.

The distribution of the participants who joined the research in terms of graduate school types are shown in the Table 1.

Table 1. The distribution of the participants in terms of the graduate school registered

\begin{tabular}{|c|c|c|}
\hline The Graduate School & $\mathrm{f}$ & $\%$ \\
\hline Education Sciences & 99 & 37.8 \\
\hline Applied and Natural Sciences & 89 & 34 \\
\hline Social Sciences & 74 & 28.2 \\
\hline Total & 262 & 100 \\
\hline
\end{tabular}

It can be seen in Table 1 that 99 of the students (37\%) are studying at the Graduate School of Education Sciences, 89 of the students (34\%) are studying at the Graduate School of Natural and Applied Sciences and 74 of the students (28.2\%) are studying at the Graduate School of Social Sciences.

Key lifelong learning competencies of the students who participated the research are given in Table 2.

Table 2. Descriptive statistics about the students' lifelong learning key competences who joined the research

\begin{tabular}{|c|c|c|c|c|c|}
\hline Categories of Competencies & $\mathbf{N}$ & Min. & Max. & $\overline{\mathbf{x}}$ & Sd \\
\hline $\begin{array}{l}\text { Competence of } \\
\text { Communication in Mother } \\
\text { Tongue }\end{array}$ & 262 & 1 & 5 & 4.59 & 0.58 \\
\hline $\begin{array}{l}\text { Competence of } \\
\text { Communication in Foreign } \\
\text { Languages }\end{array}$ & 262 & 1 & 5 & 2.60 & 1.09 \\
\hline $\begin{array}{l}\text { Mathematical Competence at } \\
\text { Science and Technology }\end{array}$ & 262 & 1 & 5 & 4.06 & 0.76 \\
\hline Digital Competence & 262 & 1 & 5 & 4.13 & 0.78 \\
\hline $\begin{array}{l}\text { Competence of Learning to } \\
\text { Learn }\end{array}$ & 262 & 1 & 5 & 4.25 & 0.72 \\
\hline Social and Civic Competences & 262 & 1 & 5 & 4.27 & 0.74 \\
\hline $\begin{array}{l}\text { Sense of Initiative and } \\
\text { Entrepreneurship Competence }\end{array}$ & 262 & 1 & 5 & 4.28 & 0.65 \\
\hline $\begin{array}{l}\text { Cultural Awareness and } \\
\text { Expression }\end{array}$ & 262 & 1 & 5 & 3.90 & 1.07 \\
\hline Total & 262 & 1 & 5 & 3.98 & 0.47 \\
\hline
\end{tabular}


As shown in Table 2, the general average of lifelong learning competences of graduate students is 3.98; the highest competence category that the students have is the competence of communication in mother tongue with the general average of 4.59. The students' seven levels of competences out of eight competences can be considered satisfactory; but they are in the level of "Hesitant" with the 2.60 average on communication in foreign languages competence.

In the research done by Karakuş [10] it was stated that the scores of lifelong learning competences of the students are above the scale scores and so the lifelong learning competences of the students are in good level. When examining the results of sub-dimesions of the scale it turned out that competences of communication in mother tongue and social and civic competences are pretty good; competence of sense of initiative and entrepreneurship, digital competences, mathematical and science competences and cultural awareness and expression competences are in good level. But the competence of communication in foreign languages is found to be below the average, in low levels.

According to the research conducted by Evin Gencel [8] teacher candidates perceive their lifelong learning competences to be at "sufficient level". While the competence of communication in mother tongue is seen as the most sufficient competence by teacher candidates, competence of communication in foreign languages and social and civic competences are determined by them to be the least sufficient competences.

According to the research conducted by Kozikoğlu [11] the lifelong learning competences of the students are at medium-level and in terms of the lifelong learning competences, the students see themselves to be at sufficient level though they do not think it is enough.

The second sub-problem of the research is the question of "Do the lifelong learning competences of graduate students significantly change according to their genders?". The results about this sub-problem are given at Table 3.

Table 3. Mann-Whitney U test results with regard to students' gender variations

\begin{tabular}{|c|c|c|c|c|c|c|c|}
\hline Categories of Competencies & Gender & $\mathrm{n}$ & Mean Rank & Total Rank & $\mathrm{U}$ & Z & $\mathrm{p}$ \\
\hline \multirow{2}{*}{ Communication in mother tongue } & Female & 123 & 142,96 & 17584,50 & \multirow{2}{*}{7138,500} & \multirow{2}{*}{$-2,465$} & \multirow{2}{*}{, $014^{*}$} \\
\hline & Male & 139 & 121,36 & 16868,50 & & & \\
\hline \multirow{2}{*}{ Communication in foreign languages } & Female & 123 & 126,89 & 15607,00 & \multirow{2}{*}{7981,000} & \multirow{2}{*}{,- 932} & \multirow{2}{*}{,351 } \\
\hline & Male & 139 & 135,58 & 18846,00 & & & \\
\hline \multirow{2}{*}{ Mathematical Competence at Science and Technology } & Female & 123 & 132,63 & 16313,00 & \multirow{2}{*}{8410,000} & \multirow{2}{*}{,- 229} & \multirow{2}{*}{, 818} \\
\hline & Male & 139 & 130,50 & 18140,00 & & & \\
\hline \multirow{2}{*}{ Digital Competencies } & Female & 123 & 128,48 & 15803,00 & \multirow{2}{*}{8177,000} & \multirow{2}{*}{,- 624} & \multirow{2}{*}{, 533} \\
\hline & Male & 139 & 134,17 & 18650,00 & & & \\
\hline \multirow{2}{*}{ Learning to Learn } & Female & 123 & 145,79 & 17932,50 & \multirow{2}{*}{6790,500} & \multirow{2}{*}{$-2,981$} & \multirow{2}{*}{, $003^{*}$} \\
\hline & Male & 139 & 118,85 & 16520,50 & & & \\
\hline \multirow{2}{*}{ Social and Civic Competencies } & Female & 123 & 138,79 & 17071,50 & \multirow{2}{*}{7651,500} & \multirow{2}{*}{$-1,496$} & \multirow{2}{*}{,135 } \\
\hline & Male & 139 & 125,05 & 17381,50 & & & \\
\hline \multirow{2}{*}{ Sense of Initiative and Entrepreneurship } & Female & 123 & 139,71 & 17184,00 & \multirow{2}{*}{7539,000} & \multirow{2}{*}{$-1,672$} & \multirow{2}{*}{,095 } \\
\hline & Male & 139 & 124,24 & 17269,00 & & & \\
\hline \multirow{2}{*}{ Cultural Awareness and Expression } & Female & 123 & 139,98 & 17217,50 & \multirow{2}{*}{7505,500} & \multirow{2}{*}{$-1,785$} & \multirow{2}{*}{, 074} \\
\hline & Male & 139 & 124,00 & 17235,50 & & & \\
\hline \multirow{2}{*}{ Total } & Female & 123 & 137,25 & 16881,50 & \multirow{2}{*}{7841,500} & \multirow{2}{*}{$-1,156$} & \multirow{2}{*}{,248 } \\
\hline & Male & 139 & 126,41 & 17571,50 & & & \\
\hline
\end{tabular}

As given in Table 3, there is a significant difference in competences of communication in mother tongue and learning to learn in terms of gender. ( $U=71338,500, p<0,05$; $U=6790,500, p<0,05$ ). The competences of communication in mother tongue and learning to learn are significantly in high levels in female students. In terms of the other competency categories there are no significant differences and it is seen that the rank mark of females are higher than rank mark of males.

When examining related researches; in a work conducted by Şahin, Akbaşlı and Yanpar Yelken [14] it was stated that gender is not an effective factor in terms of lifelong learning competences. In a work conducted by Kozikoğlu [11] it was stated that gender has not an important role in differentiation of lifelong learning competences levels. Also in a work conducted by Şahin and Arcagök [15] it was pointed out that gender is not an effective factor on sub-dimensions of lifelong learning competences.

However, in a work conducted by Evin Gencel[8] gender is a factor that causes significant differences in perceptions of lifelong learning competences of teacher candidates.

The third sub-problem of the research is the question of "Is there any significant difference between the levels of graduate students lifelong learning competences and the stage they are in graduate education?" The results concerning this sub-problem are given at Table 4. 
Table 4. The results concerning the levels of graduate students according to Mann-Whitney U test

\begin{tabular}{|c|c|c|c|c|c|c|c|}
\hline Categories of Competencies & Stage & $\mathrm{n}$ & Mean Rank & Sum of Ranks & $\mathrm{U}$ & Z & $\mathrm{p}$ \\
\hline \multirow{2}{*}{ Communication in mother tongue } & Studying stage & 166 & 124,73 & 20705,50 & 6844,500 & \multirow{2}{*}{, $042 *$} & \multirow{2}{*}{0} \\
\hline & Dissertation stage & 96 & 143,20 & 13747,50 & $-2,034$ & & \\
\hline \multirow{2}{*}{ Communication in foreign languages } & Studying stage & 166 & 128,49 & 21329,50 & 7468,500 & \multirow{2}{*}{, 395} & \multirow{4}{*}{, 731} \\
\hline & Dissertation stage & 96 & 136,70 & 13123,50 & -850 & & \\
\hline \multirow{2}{*}{$\begin{array}{l}\text { Mathematical Competence at Science } \\
\text { and Technology }\end{array}$} & Studying stage & 166 & 132,71 & 22029,50 & 7767,500 & & \\
\hline & Dissertation stage & 96 & 129,41 & 12423,50 & -344 & & \\
\hline \multirow{2}{*}{ Digital Competencies } & Studying stage & 166 & 126,94 & 21071,50 & 7210,500 & \multirow{2}{*}{, 188} & \\
\hline & Dissertation stage & 96 & 139,39 & 13381,50 & -317 & & \\
\hline \multirow[b]{2}{*}{ Learning to Learn } & Studying stage & 166 & 130,81 & 21714,00 & 7853,000 & \multirow[b]{2}{*}{, 840} & \\
\hline & Dissertation stage & 96 & 132,70 & 12739,00 &,- 202 & & \\
\hline \multirow{2}{*}{ Social and Civic Competencies } & Studying stage & 166 & 131,13 & 21767,50 & 7906,500 & \multirow{2}{*}{ „915 } & \\
\hline & Dissertation stage & 96 & 132,14 & 12685,50 &,- 106 & & \\
\hline \multirow{2}{*}{$\begin{array}{l}\text { Sense of Initiative and } \\
\text { Entrepreneurship }\end{array}$} & Studying stage & 166 & 130,46 & 21656,50 & 7795,500 & \multirow{2}{*}{, 767} & \multirow{2}{*}{0} \\
\hline & Dissertation stage & 96 & 133,30 & 12796,50 &,- 296 & & \\
\hline \multirow{2}{*}{ Cultural Awareness and Expression } & Studying stage & 166 & & 22090,00 & 7707,000 & \multirow{2}{*}{ „644 } & \\
\hline & Dissertation stage & 96 & $133,07128,78$ & 12363,00 &,- 463 & & \\
\hline \multirow{2}{*}{ Total } & Studying stage & 166 & 127,16 & 21108,00 & 7247,000 & \multirow{2}{*}{2,222} & \\
\hline & Dissertation stage & 96 & 139,01 & 13345,00 & $-1,221$ & & \\
\hline
\end{tabular}

As seen in Table 4, there is a significant difference between the graduate studying stages and dissertation stages of the students at the competence levels of communication in mother language. ( $U=6844,500 ; p<0,05)$. It can be seen that the level of competence of communication in mother tongue of the students in dissertation stage is significantly higher. In terms of the other competence categories there was no statistically significant difference. However, the competences of communication in foreign languages, digital competences, competences of learning to learn, social and civic competences and initiative and entrepreneurship competences of the students in dissertation stages are high though lower than the rank mark. Examining all competences show that the students in dissertation stage are in better state however, there is not a significant difference.

The fourth sub-problem of the research is the question of "Do the levels of lifelong learning competences of graduate students change significantly according to their graduate school types?" The results concerning this sub-problem are given at Table 5 .

Table 5. The results concerning the graduate school type factor according to Kruskal Wallis $\mathrm{H}$ test

\begin{tabular}{|c|c|c|c|c|c|c|}
\hline Category of Competence & Graduate School & $\mathbf{n}$ & Mean Rank & sd & $\mathbf{x}^{2}$ & $\mathbf{p}$ \\
\hline \multirow{3}{*}{ Communication in Mother Tongue } & Education Sciences & 99 & 139,99 & \multirow{3}{*}{2} & \multirow{3}{*}{2,292} & \multirow{3}{*}{,318 } \\
\hline & Social Sciences & 74 & 126,59 & & & \\
\hline & Natural and Applied Sciences & 89 & 126,13 & & & \\
\hline \multirow{3}{*}{ Communication in Foreign Languages } & Education Sciences & 99 & 120,81 & \multirow{3}{*}{2} & \multirow{3}{*}{7,497} & \multirow{3}{*}{, $024 *$} \\
\hline & Social Sciences & 74 & 124,58 & & & \\
\hline & Natural and Applied Sciences & 89 & 149,15 & & & \\
\hline \multirow{3}{*}{$\begin{array}{l}\text { Mathematical Competence at Science and } \\
\text { Technology }\end{array}$} & Education Sciences & 99 & 140,74 & \multirow{3}{*}{2} & \multirow{3}{*}{20,988} & \multirow{3}{*}{, $000^{*}$} \\
\hline & Social Sciences & 74 & 98,24 & & & \\
\hline & Natural and Applied Sciences & 89 & 148,87 & & & \\
\hline \multirow{3}{*}{ Digital Competence } & Education Sciences & 99 & 142,59 & \multirow{3}{*}{2} & \multirow{3}{*}{4,560} & \multirow{3}{*}{, 102} \\
\hline & Social Sciences & 74 & 118,55 & & & \\
\hline & Natural and Applied Sciences & 89 & 129,93 & & & \\
\hline \multirow{3}{*}{ Learning to Learn } & Education Sciences & 99 & 132,35 & \multirow{3}{*}{2} & \multirow{3}{*}{, 159} & \multirow{3}{*}{,924 } \\
\hline & Social Sciences & 74 & 128,66 & & & \\
\hline & Natural and Applied Sciences & 89 & 132,91 & & & \\
\hline \multirow{3}{*}{ Social and Civic Competences } & Education Sciences & 99 & 136,26 & \multirow{3}{*}{2} & \multirow{3}{*}{, 892} & \multirow{3}{*}{,640 } \\
\hline & Social Sciences & 74 & 131,71 & & & \\
\hline & Natural and Applied Sciences & 89 & 126,03 & & & \\
\hline \multirow{3}{*}{ Sense of Initiative and Entrepreneurship } & Education Sciences & 99 & 126,81 & \multirow{3}{*}{2} & \multirow{3}{*}{2,987} & \multirow{3}{*}{,225 } \\
\hline & Social Sciences & 74 & 124,49 & & & \\
\hline & Natural and Applied Sciences & 89 & 142,55 & & & \\
\hline \multirow{3}{*}{ Cultural Awareness and Expression } & Education Sciences & 99 & 140,62 & \multirow{3}{*}{2} & \multirow{3}{*}{9,511} & \\
\hline & Social Sciences & 74 & 109,55 & & &, $009 *$ \\
\hline & Natural and Applied Sciences & 89 & 139,61 & & & \\
\hline & Education Sciences & 99 & 133,04 & & & \\
\hline Genel & Social Sciences & 74 & 114,95 & 2 & 5,832 & ,054 \\
\hline & Natural and Applied Sciences & 89 & 143,56 & & & \\
\hline & Total & 262 & & & & \\
\hline
\end{tabular}


A shown in Table 5, the key lifelong learning competences as a whole and the competences of communication in mother tongue, digital competences, competences of learning to learn, social and civic competences and initiative and entrepreneurship competences of the students do not differ according to the graduate school type. $\left(\mathrm{x}^{2}=5,832 \mathrm{p}<0,05 ; \mathrm{x}^{2}=2,292\right.$, $\left.\mathrm{p}<0,05 ; \mathrm{x}^{2}=4,560 ; \mathrm{p}<0,05 ; \mathrm{x}^{2}=0,159 ; \quad \mathrm{p}<0,05 ; \mathrm{x}^{2}=0,892 ; \mathrm{p}<0,05 ; \mathrm{x}^{2}=2,987 ; \quad \mathrm{p}<0,05\right)$

According to the work conducted by Karakuş [10] the lifelong learning competences do not differ in different graduate school students.

It can be seen that there is a significant difference in terms of the competences at communication in foreign languages $\left(x^{2}=7,497 ; \quad p<0,05\right)$, competence of basic mathematics and science $\left(x^{2}=20,988 ; p<0,05\right)$ and competences cultural awareness and expression $\left(x^{2}=9,511 ; p<0,05\right)$ according to the graduate school types of the students. With the aim of determining between which groups is there a significant difference, for the each group Mann-Whitney $U$ test and Bonferroni correction were conducted. And because there are three group duos, the significance level was taken as $0.05 / 3=0.0167$ in Mann-Whitney U test.

The comparison of factor of students' graduate school types are given at Table 6.

Table 6. The results of Mann-Whitney U test on the comparison of groups which differentiate according to the graduate school types of the students.

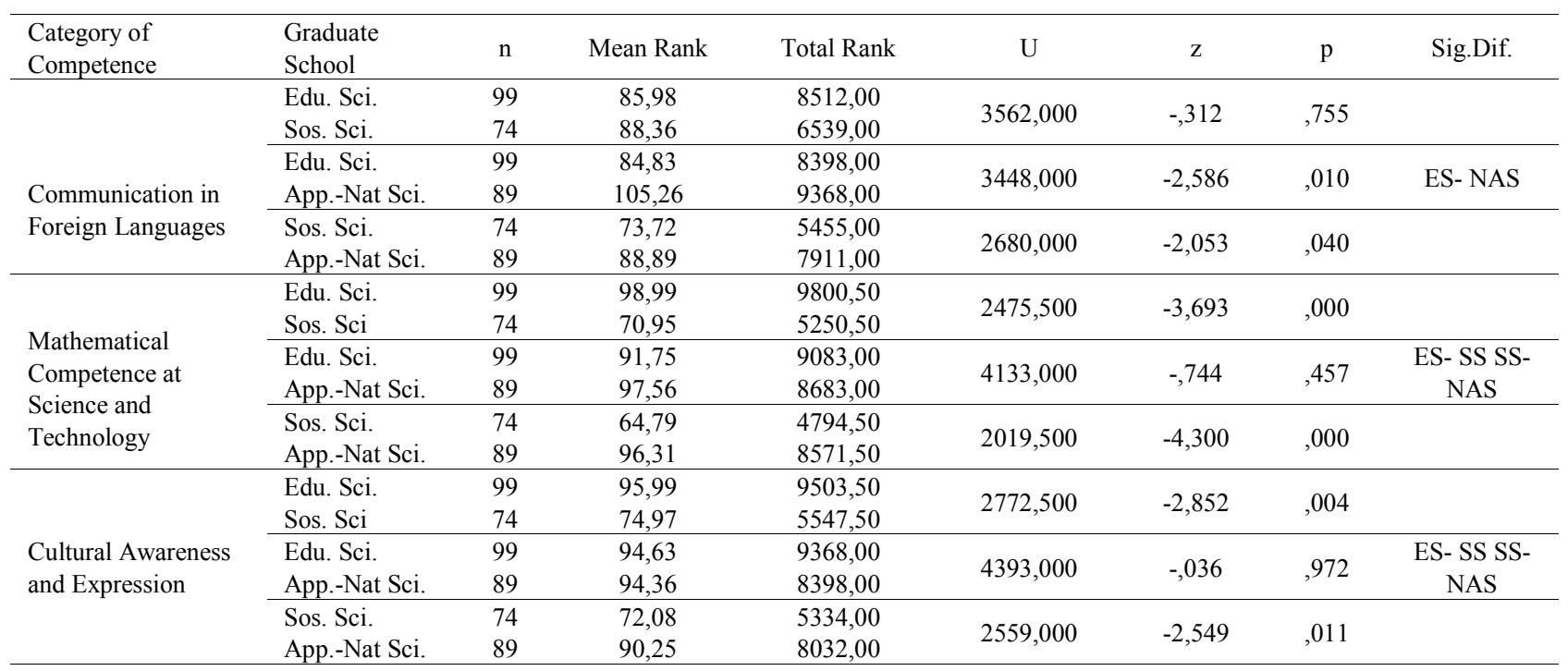

$\mathrm{p}<0.0167$

As given in Table 6, the key competence of communication in foreign languages of the students differ significantly according to the graduate school types; especially Graduate School of Natural and Applied Sciences students seem to have higher scores than the students of Graduate School of Education ( $U=3448,000, p<.0167)$. So the sub-dimensions of competence of communication in foreign languages of the Graduate School of Natural and Applied Sciences students are in better state than the students of Graduate School of Education students. There was not a significant difference in terms of sub-dimensions of competence of communication in foreign languages between the students of Graduate School of Social Sciences and the students of Graduate School of Natural and Applied Sciences( $U=3562,000, p<.0167),(U=2680,000, p<.0167)$.

When Mathematical competences and basic competences in science and technology is examined it is seen that there is a significant difference between the students of Graduate School of Education and Graduate School of Social Sciences students $(\mathrm{U}=2475,500, \mathrm{p}<.0167)$ and Graduate School of Natural and Applied Sciences students have higher scores than the students of Graduate School of Social Sciences $(U=2019,500, p<.0167)$. There are no significant difference between the scores of Graduate School of Education students and Graduate School of Natural and Applied Sciences students $(\mathrm{U}=4133,000, \mathrm{p}<.0167)$.

When the competence of cultural awareness and expression is examined it can be seen that the scores of Graduate School of Education students are better than the scores of Graduate School of Social Sciences students $(\mathrm{U}=2772,500, \mathrm{p}<.0167)$, the scores of Graduate School of Natural and Applied Sciences students are higher than the scores of Graduate School of Social Sciences students $(\mathrm{U}=2559,000, \mathrm{p}<.0167)$. There was no significant difference between the scores of Graduate School of Education students and Graduate School of Natural and Applied Sciences students in sub-dimensions of competence of cultural awareness and expression $(\mathrm{U}=4393,000, \mathrm{p}<.0167)$.

\section{Results, Conclusions and Recommendations}

It was determined that out of the all key lifelong learning competences graduate students who joined the research see themselves the most competent in competence of 
communication in mother tongue and the least competent in the competence of communication in foreign languages. The lifelong learning competences of the students are in the level of 'I agree', which means their lifelong learning competences are in high levels.

In the researchers conducted by Şahin, Akbaşlı and Yanpar yelken [10] the teacher candidates see themselves 'sufficiant' in lifelong learning competences and their competence of communication in foreign languages are low. The research conducted by Yavuz Konokman and Yanpar Yelken [18] it was determined that the lifelong learning awarenesses of the instructors are high. The research conducted by Yaman [17] shows that lifelong learning tendencies of the teachers are in high levels.

The research showed that there are significant differences in terms of lifelong learning competences of graduate students between the competences of communication in foreign languages and competence of learning to learn; female students have higher scores. In the other categories of competences and on total there are no significant differences in lifelong learning competences depending on genders. However, rank marks of female students are higher than male students.

In the research conducted by Şahin, Akbaşlı and Yanpar Yelken [14] it was concluded that gender is not an effective factor on key lifelong learning competences. However, in the research done by Evin Gencel [8] the perceptions of lifelong learning competences differentiate depending on genders. Also in the research done by Yavuz Konokman and Yanpar Yelken [18] it showed that the perceptions of lifelong learning competences of instructors differ depending on genders.

On the factor of graduate students stages of majoring, lifelong learning competences of the students who are in the dissertation stage have better scores in competence of communication in mother tongue. In the other competence categories and on total there are no significant differences depending on the stage of graduate students. In the research done by Karakuş [10] the levels of lifelong learning competences of vocational school of higher education students gets higher as their grades are higher.

It is seen that graduate students competences of communication in mother tongue, mathematical competences in basic science and technology, cultural awareness and expression competences differ significantly depending on the graduate school types. It is conducted that the levels of key lifelong learning competences are the highest in students of Graduate School of Natural and Applied Sciences and lowest in students of Social Sciences. In the research done by Kozikoğlu [11] it is stated that there is a significant effect of the graduate school type or department of the students on lifelong learning competences.

According to the results of research it is seen that graduate students competences of communication foreign languages, mathematical competences in basic science and technology and competences of cultural awareness and expression differ significantly depending on the graduate school type. Tests were conducted to determine between which groups are there significant differences and it is seen that Graduate School of Natural and Applied Sciences students have higher scores in competence of foreign languages. Mathematical competences in basic science and technology and competences of cultural awareness and expression the scores of Graduate School of Social Sciences are found to be lower than the scores of the students of Graduate School of Education Sciences and Graduate School of Natural and Applied Sciences. So concerning the education backgrounds of Graduate School of Social Sciences students, it is suggested that the lessons of foreign languages, science, technology, mathematics, cultural awareness and expression should be increased and if necessary the curriculum change should be done. And with the aim of increasing the competences of communication in foreign languages of Graduate School of Education Sciences students, the classes of foreign languages, curriculum topics, methods and techniques should be examined and due precautions should be taken.

According to the results of research it is seen that concerning the factor of having the key lifelong learning competences depending on the graduate school type, Graduate School of Natural and Applied Sciences students are in the best state and Graduate School of Social Sciences students are in the lowest state. So by examining the education backgrounds of the students of Graduate School of Social Sciences, with the aim of increasing their competences and qualifications there must be regulations on the education system.

\section{Note}

*The abstract of this paper was presented at 2nd International Conference on Lifelong Learning and Leadership for All (ICLEL-16), in Liepaja on July, 21-23, 2016.

\section{REFERENCES}

[1] Aksoy, M. (2008). The Impact of the Principles of Life Long Learning and Career Guidance on Employability: A Research Study of Hotels. Unpublished Doctorate Thesis, Gazi University, Institute of Educational Sciences, Ankara.

[2] Büyüköztürk, Ş. (2012). Sosyal bilimler için veri analizi el kitab1 (16. Bask1). Ankara: Pegem Yayınevi.

[3] Dilci, T (2009). Evaluating the Situation of Postgraduate Education in Educational Sciences From The Perspective of Students and Academicians. Unpublished Doctorate Thesis, Firat University, Institute of Social Sciences, Elazığ.

[4] Doğan, M. (1996). Foreign language learning and foreign language teaching. Bilge Dergisi, (10), 11-14.

[5] Epçaçan, C. (2013). An Example Study About Level of 
Handling Lifelong Learning Skills in Textbooks. Adıyaman Üniversitesi Sosyal Bilimler Enstitüsü Dergisi Türkçenin Eğitimi Öğretimi Özel Sayısı. (11), pp. 359-379.

[6] European Commission (2002). European report on quality indicators of lifelong learning. Fifteen quality indicators. European Commission report, Directorate- General for Education and Culture, Brussels. From $<$ http://www.aic.lv/ace/ace_disk/Bologna/contrib/EU/report qual\%20LLL.pdf $>$ (Retrieved on 29 October 2016).

[7] European Commission, (2007). Key competences for lifelong learning European reference. From $<$ https://www.britishcouncil.org/sites/default/files/youth-in-a ction-keycomp-en.pdf $>$ (Retrieved on 29 October 2016).

[8] Evin Gencel, İ. (2013). Prospective teachers' perceptions towards lifelong learning competencies. Eğitim ve Bilim. 38 (170), pp. 237-252.

[9] Karasar, N.(2007). Bilimsel araştırma yöntemi (17. Baskı). Ankara: Nobel Yayın Dağıtım.

[10] Karakuş, C. (2013). Lifelong Learning Competences of Vocational School Students. Eğitim ve Öğretim Araştırmaları Dergisi. 2 (3), pp. 26-35.

[11] Kozikoğlu, İ. (2014). Analysis of University and Vocational School Students' Lifelong Learning Competences. Journal of Instructional Technologies \& Teacher Education 3 (3), 29-43.
[12] Özden, Y. (2005). Eğitimde yeni değerler (6. Bask1). Ankara: Pegem A yayınc1lik.

[13] Poyraz, H., \& Titrek, O. (2013). Türkiye'de Hayat Boyu Öğrenmenin Geliştirilmesi. Abant İzzet Baysal Üniversitesi Eğitim Fakültesi Dergisi, 115-131.

[14] Şahin, M., Akbaşlı ,S. ve Yanpar Yelken T. (2010). Key competences for lifelong learning: the case of prospective teachers. Educational Research And Review, 5 (10), 545-556.

[15] Şahin, Ç. ve Arcagök, S. (2014). Examination of the teachers' lifelong learning competences levels in terms of some variables. Adıyaman Üniversitesi Sosyal Bilimler Enstitüsü Dergisi. (16), 394-417.

[16] Ulusal Ajans, (2012). Youthpass Kılavuzu. AB Eğitim ve Gençlik Programları Merkezi Başkanlığı, Ankara.

[17] Yaman, F. (2014). Investigating of Life Long Learning Tendency of Teachers (The Example of Diyarbakır). Graduate Thesis, Dicle University, Institute of Educational Sciences, Diyarbakir.

[18] Yavuz Konokman, G. ve Yanpar Yelken, T. (2014). The Perceptions of Academicians in Education Faculties on Their Lifelong Learning Competencies. Hacettepe Üniversitesi Eğitim Fakültesi Dergisi. 29 (2), 267-281. 